The research program of the Center for Economic Studies (CES) produces a wide range of theoretical and empirical economic analyses that serve to improve the statistical programs of the U.S. Bureau of the Census. Many of these analyses take the form of CES research papers. The papers are intended to make the results of CES research available to economists and other interested parties in order to encourage discussion and obtain suggestions for revision before publication. The papers are unofficial and have not undergone the review accorded official Census Bureau publications. The opinions and conclusions expressed in the papers are those of the authors and do not necessarily represent those of the U.S. Bureau of the Census. Republication in whole or part must be cleared with the authors.

\title{
CRIME'S IMPACT ON THE SURVIVAL PROSPECTS OF YOUNG URBAN SMALL BUSINESSES
}

\author{
by \\ Timothy Bates * \\ Wayne State University \\ and \\ Alicia Robb * \\ University of California, Santa Cruz
}

CES 07-30 October, 2007

All papers are screened to ensure that they do not disclose confidential information. Persons who wish to obtain a copy of the paper, submit comments about the paper, or obtain general information about the series should contact Sang V. Nguyen, Editor, Discussion Papers, Center for Economic Studies, Bureau of the Census, 4600 Silver Hill Road, 2K132F, Washington, DC 20233, (301-763-1882) or INTERNET address sang.v.nguyen@census.gov. 


\begin{abstract}
High prevailing levels of criminal activity have numerous impacts on the viability of urban small businesses and the various impacts are not uniformly negative. It is the negative impacts, however, that are most often noted. Either the perception or reality of rampant crime can scare away customers, potential employees, lending institutions, even casualty insurance underwriters. Yet, competitors may also be driven away. Operating in a high-crime area can be advantageous, on balance, for some firms. Our analysis of nearly 5,000 urban businesses started between 1986 and 1992 indicates that those most seriously impacted by crime exhibit no measureable disadvantage regarding firm size, capitalization, survival rates, or other traits, relative to firms whose owners report that crime has not impacted them negatively.
\end{abstract}

KEY WORDS: small business survival patterns

* The research in this paper was conducted while one of the authors was a Special Sworn Status researcher of the U.S. Census Bureau at the Center for Economic Studies. Research results and conclusions expressed are those of the authors and do not necessarily reflect the views of the Census Bureau. This paper has been screened to insure that no confidential data are revealed. The data can be obtained at a Census Research Data Center or at the Center for Economic Studies (CES) only after approval by the CES and IRS. 


\section{$\underline{\text { Introduction }}$}

Conventional wisdom suggests that business activity in urban communities is often discouraged when high levels of crime prevail. People seeking to establish new businesses tend to stay away: the risk of failure is presumably heightened while the likely degree of success is lowered. Yet, our search of the social science literature suggests that no empirical link has been established to date between crime levels and the viability of small businesses. Evidence supporting the prevailing conventional wisdom consists primarily of assertions without empirical grounding.

Crime's impact on small-business survival, properly understood, tends to shape the very nature of urban businesses, particularly those in fields where face-to-face customer contact is frequent. In high-crime niches, nonminority white owners are underrepresented, while minority and/or immigrant owners are present in abundant numbers. Retail firms are heavily overrepresented in the category of small firms most adversely impacted by crime. Our analyses indicate that, on balance, young firms operating in high-crime niches in urban America appear not to be disadvantaged by crime.

Crime’s impact may certainly be harmful, other factors constant, but the crux of our findings is that other factors are not constant. Firms most negatively impacted by crime are not found to be less viable than otherwise identical owners/firms reporting that crime has no impact on their businesses. High-crime niches, in fact, may be rational choices for some business owners, present and potential, in the narrow sense that firm survival prospects actually may be superior, relative to other urban opportunities. 


\section{The Controversy}

Porter (1995) observes serious impediments to inner-city economic development rooted in the reality and perception of abundant criminal activity. Crime against property raises costs of doing business in the inner city. Crime against employees and customers “creates an unwillingness to work and patronize inner city establishments...” (p. 63). It is noteworthy that Porter mentioned "the perception of abundant criminal activity"; in the same article, he opines that the perception is indeed greater than the reality.

Other disadvantages prevail. High crime rates make it difficult to obtain casualty insurance and raise the cost of such insurance (Yoon, 1997; Squires, 1999). Financial institutions are hesitant to lend to small businesses in this environment; commercial investment is thus hindered (Immergluck, 1999; Craig, et al., 2007).

Scaring away customers, potential employees, lending institutions, even casualty insurance underwriters, however, is only a partial listing of crime’s possible impacts. Competitors may also be driven away; underutilized facilities might be available at modest rents; underemployed neighborhood residents may provide a readily available labor pool (Yoon, 1997; Porter, 1997). Operating in a high-crime niche may be advantageous, on balance, for some firms. All of these speculations are discussed in the applicable social science literature, yet testable hypotheses have been missing because the empirical evidence that would allow them to be spelled out and investigated has been in short supply.

Our search for empirical evidence concerning crime’s impact on urban business viability took us beyond the realm of research that is strictly academic. The consultant reports generated by Michael Porter's Initiative for a Competitive Inner City (ICIC) offer 
some insight. A survey of 36 retail business owners revealed that shoplifting, vandalism, and the general perception of crime, in that order, were cited as "challenges of the innercity market” (Boston Consulting Group, 1998, p.15). Although making no claims about the representativeness of this business sample or its applicability to small business viability more broadly, the report did suggest that crime’s magnitude may be exaggerated and that its manifestations were manageable if business managers dealt pragmatically with prevention strategies.

Minority presence appears to correlate positively with perceptions that crime is creating a poor environment for new firm creation and profitable operation of existing businesses. Immergluck has documented that commercial investment in Chicago neighborhoods has declined as percentages of black and Hispanic residents grow, "even after controlling for income and population changes” (1999, p. 15). He identifies crime as an unmeasured factor not controlled for in his analysis. One interpretation is that increased numbers of minority residents are perceived as a proxy for rising crime, hence reducing commercial investment. This rising crime may be real or perceived: if it causes bank hesitancy to lend and owner aversion to firm creation and expansion, then it matters little whether the problem is one of reality or perception. Business activity is discouraged either way.

Is crime’s impact a major impediment to business viability in urban America? Is this impact properly thought of primarily as a minority phenomenon? How much of crime's impact is rooted in perception as opposed to reality? Absent sophisticated data capable of controlling for crime's impact, we are left with a literature full of speculations and a conventional wisdom lacking empirical underpinnings. 
Buried in a little-known U.S. Bureau of the Census small-business database (the CBO database) lie the overlooked responses of many thousands of individual smallbusiness owners to the question, "What was the impact of crime on the profitability of this business?" In this study, we utilize these data to examine small businesses that began operations from 1986-1992 in urban America. We focus particularly on the subset of business owners who responded "strong negative impact" to the above question concerning crime’s impact. How do these firms/owners differ from urban small businesses that are less or unaffected by crime?

The CBO database is a uniquely powerful small business micro-data source, providing a wealth of information on firm and owner traits of many thousands of individual businesses, including owner demographics, education and experience, firm financing, firm operating-environment variables, and numerous others.

We utilize these data to explore crime’s impact upon urban young firms, delineating those actively functioning in 1992 into two groups -- those still operating versus those shutting down and going out of business by late 1996. Further, we compare the traits of those most impacted by crime to the broader universe of young small firms doing business in urban America in 1992. The former stand out as being heavily concentrated in one line of business -- retailing -- and they are relatively more numerous in firms that cater to a neighborhood clientele (consumer services and, particularly, smallscale retail firms). Relative to the neighborhood-oriented businesses, firms serving broader geographically-defined markets - city-, county-, or metro-area-wide - have a different industry mix (construction, manufacture, wholesale, business services, largescale retail) and are less apt to report that their profitability is hurt by crime. Firms 
reporting severe negative impacts from crime, finally, are over represented in the minority-market niche.

Indeed, among all of the young urban small firms, 3.3 percent (according to the nationally representative $\mathrm{CBO}$ database) reported a strong negative impact of crime on business profits. In the neighborhood-clientele-oriented segment, a higher 5.6 percent of the firms were similarly impacted (table one). Most firm owners - in neighborhood markets or otherwise -- attribute no impact to crime as a determinant of firm profitability.

It is noteworthy how dramatically table one's three small-business groupings - 1) all young urban firms, 2) firms reporting strong, negative impact of crime, and 3) firms serving a neighborhood clientele -- differ from each other in terms of both firm and owner characteristics. Firm size, measured by annual sales, firm capitalization, owner race, ethnicity traits, owner education levels, and other factors exhibit widely varying mean values. Firms in the high-crime-impact group stand out as the larger, more established, better capitalized firms, on average, and their rates of closure through yearend 1996 (16.5\%) are markedly lower than those of either young urban firms generally (23.2\%), or neighborhood-oriented firms specifically (22.9\%).

\section{Table one here}

In considering the investment potential of small-firm startups in stigmatized niches - such as high crime subfields - mainstream microeconomic theory offers a provocative hypothesis: profit-seeking firms achieve returns in high-crime fields that are neither higher nor lower than the returns available to business investments throughout all segments of urban America. Why should investments in high-crime fields be less attractive than those accessible in low-crime niches? If systematic differentials in actual 
or expected returns typified high- and low-crime urban submarkets (or particular industry subgroups), then firms in the low-return areas (or industries), microeconomic theory predicts, would choose to contract and invest their resources in alternatives offering superior returns. This is the crux of rational profit-maximizing firm behavior.

Microeconomic theory predicts that the dynamic of businesses seeking to maximize returns on their production inputs will continue until net yields on investment alternatives equalize across alternatives. If low-crime sectors offer higher returns to small business startups, then investments will be directed toward realizing those higher returns. The process of firm creation and expansion in attractive opportunities, combined with disinvestment in "unattractive” niches, will continue until returns have equalized across alternatives.

An extension of this textbook prediction of microeconomic theory suggests that, at equilibrium, returns may actually be higher, on average, in the unattractive (high crime) niches. Assume that individuals contemplating creating new businesses in highcrime urban subfields anticipate, on average, that in the course of operating their firm, they face a 2.1 percent risk of being shot or stabbed. Low-crime alternative opportunities, in contrast, are expected to offer a 0.1 percent prospect of being shot or stabbed. Perfect equality in expected firm profitability across high-crime and low-crime alternatives would not induce owner entry into high-crime niches because greater owner fear of being shot/stabbed negates this attraction. Rather, a premium would have to be offered to offset the negative utility that potential owners attach to the 2.1 percent probability of being shot or stabbed. In equilibrium, expected returns in the high-crime niches would therefore exceed those in low-crime areas, and the magnitude of those higher returns reflects the 
premium demanded by owners to compensate them for their greater fear of serious bodily harm in high-crime (as opposed to low-crime) small-business niches.

\section{The CBO Database and Specification of Sub-Markets in Urban Areas}

Terms like "urban areas" require clarification as a prerequisite to conducting our econometric analyses of the urban sub-markets served by small businesses. We have chosen not to constrain the geographic scope of our econometric analyses of urban smallfirm survival patterns to central cities; our geographic scope is the metropolitan area. All small firms located in urban areas that are classified by the Census Bureau as metropolitan areas are included in our $\mathrm{CBO}$ database sampling frame; all firms located outside of metro areas are excluded. Our precise specification of small business market segments has been heavily shaped, as well, by the nature of the questions posed by Census to the small business owners who responded to the $\mathrm{CBO}$ questionnaire back in late 1996.

The owner responses to the CBO survey describe urban firms along several target-market dimensions: 1) clientele served - minority vs. nonminority, 2) geographic scope of market served - local/neighborhood vs. city/county/national. Our analysis files of CBO data are structured along geographic-scope-of-market dimensions. It is noteworthy that neighborhood-oriented firms serve household clienteles predominantly, while broad-market-oriented firms (those serving city, regional, national clienteles) most often sell their products to other businesses and nonprofit clients, predominantly government in nature. 
Next, this study utilizes "negatively impacted by crime" as an explanatory variable in the context of logistic regression exercises investigating survival patterns among two groups of young urban small businesses: those serving 1) neighborhood, as opposed to 2) broad-market clienteles. Controlling for relevant firm and owner characteristics, as well as target-market identifiers, young firms actively operating in metropolitan areas in both 1992 and 1996 are distinguished from firms active in 1992 but closed down and out of business in 1996. Firms changing ownership during the 1992 1996 period were tracked and counted as active firms as long as they were still actively selling products in 1996.

Existing studies utilizing CBO data to delineate firm survival patterns through 1996 have shown that abundant owner human capital, in conjunction with abundant firm financial capitalization, typifies those most likely to survive (Fairlie and Robb, 2007; Bates, 1997). Furthermore, it is the larger scale, more established businesses that tend to remain active, while the very youngest firms are particularly vulnerable to closure and discontinuance of business operations.

Our analysis of small-firm survival patterns utilizes CBO data describing urban firms that began operations between 1986 and 1992: logistic regression analysis is utilized to delineate the active from the discontinued business ventures. These small-firm CBO data were constrained to include only those firms with owners actively involved in running the business in 1992. Attempting to weed out "casual" businesses, we excluded those reporting sales revenues under $\$ 5,000$ in 1992, a step that reduced the sample size substantially. To delineate small firms still active in 1996 from those that discontinued 
during the 1992-1996 period, we utilize firm, owner, and environmental traits as explanatory variables.

A large, growing body of literature predicts increased survival odds for wellcapitalized small firms run by owners having the human capital (expertise, experience) appropriate for operating a viable venture. Owner human capital is described in the CBO data by multiple qualitative and quantitative measures of education and experience. Two types of work experience have strongly predicted improved firm survival prospects in recent studies. First, prior work experience in a business whose products were similar to those provided by the owner's current venture is important (Bruderl, et al., 1992; Fairlie and Robb, 2007). Second, prior experience working in a family-owned business increases the likelihood of young firm success and survival (Fairlie and Robb, 2007). Furthermore, previous findings indicate that highly educated owners are more likely than poorly educated ones to operate firms that remain active (Bates, 1990).

The dynamics of small firm survival depend upon a variety of factors beyond owner human capital in the firm. Very young firms are more volatile and failure-prone than ventures that have built up customer goodwill and an established client base (Jovanovic, 1982; Bates, 1997). A possible short-cut to successful firm creation entails entering business by purchasing an ongoing firm that already has an established customer base.

Few studies have examined any sort of explanatory variables that describe the operating environment of small firms, including the client subgroups that firms target; data constraints are perhaps the reason for this exclusion. Bates (1989) found that firms serving predominantly minority clienteles were more likely to go out of business than 
firms targeting nonminorities, holding other factors constant. Our logistic regression analysis of young firm survival patterns includes an identifier of firms that derive the majority of their sales from minority clients. All relevant explanatory variables are defined in the attached Data Appendix: the CBO Data.

All of the above explanations of firm viability and survival are essentially hypotheses, which we examine in this study to explain closure patterns among young firms doing business in metropolitan America. Once firm, owner, and environmental traits are controlled for statistically, owner demographic traits - race and gender -- are expected to have little impact upon firm closure patterns. We undertake our logistic regression analysis to isolate crime's possible impacts by first controlling for impacts of the applicable characteristics discussed above.

Recall that firms reporting strong negative impacts of crime on profitability (table one) were considerably less likely (16.5\% closure) than young urban firms generally (23.2\% closure) to go out of business by late 1996. Summary statistics alone, however, do not demonstrate that high-crime-impacted firms are less prone to go out of business than young urban small firms generally. Relative to their urban counterparts, the highcrime-impacted firms are older, larger, better capitalized small businesses (table one) and each of these characteristics is associated with heightened survival prospects. To isolate possible consequences of crime's impact, we proceed by controlling econometrically for differences in firm, owner, and environmental traits. This is undertaken in table two's logistic regression exercise: firms active in late 1996 are assigned a dependent value of one; discontinued firms are zeros. 
Table two's logit exercises delineate firms discontinuing operations in the 19921996 period from those still active at the end of 1996. Our CBO sample of nearly 5,000 small firms includes all that meet the selection criteria of being young, urban, and active in 1992. The underlying CBO data (and regression results) are weighted to be nationally representative of small firms meeting these selection criteria.

Separate logistic regressions are estimated for firm groups defined by geographic scope of market served. The applicable market-segment-defined subgroups distinguish two market orientations: 1) those catering to a specific neighborhood market, versus 2) those serving city-, county-, region-, or nation-wide clients. The former firm subgroup is more heavily impacted by crime (5.6\% of firms report serious impacts) than the latter (where 2.6\% of the firms experienced serious negative impacts). These firm subgroups were identified using owner responses to the CBO survey instrument. Similarly, the “minority market” variable separated the firms into subgroups of those selling to clients who are either 1) predominantly minority or 2) predominantly nonminority.

For neighborhood-oriented firms, findings of table two's logistic regression exercise include a highly positive, statistically significant high-crime-impact variable coefficient, unambiguously indicating that owners citing crime as a major problem experienced heightened firm survival prospects, other things equal. This counterintuitive finding stands in contradiction to the previously discussed conventional wisdom often found in scholarly studies, but it is consistent with the predictions of microeconomic theory. The actual positive net impact of crime on the likelihood of firm survival is consistent with the hypothesis that owners entering high-crime niches are lured, at equilibrium, by opportunities sufficiently attractive to compensate for the disutility of 
operating in a high-crime environment. Crime itself is not a plus; rather, attractive opportunities that lure entrepreneurs into high-crime fields must be sufficiently appealing to overcome disadvantages posed by crime.

\section{Table two here}

Heightened likelihood of firm survival (table two) is negatively associated with serving a minority-clientele for firms with a neighborhood orientation; the minorityclientele coefficient was negative but statistically insignificant in the logistic regression exercise delineating active from closed firms operating in the broad marketplace. This is noteworthy because firms serving minority clients predominantly are shown below to be more prone to problems rooted in high crime levels. Small firm closure, furthermore, was associated with firm size: those reporting no payroll to the Internal Revenue Service were more likely to go out of business than firms utilizing paid employees (table two).

The factors that predict firm survival through 1996 broadly mirror those highlighted by previous studies of small-business discontinuance patterns. Highly educated owners and the entrepreneurs with prior experience in a similar line of business were generally the ones whose firms were most likely to be active at the end of 1996 . The very youngest firms were most prone to discontinue operations. Impacts of startup capitalization levels on firm survival patterns were rather weak - positive and statistically significant for broad-market firms but insignificant for neighborhood businesses. Explanatory variables measuring firm startup capitalization and paid employee presence are actually highly correlated; dropping either variable causes the statistical significance of the other to rise. 
Minority and immigrant owners of neighborhood businesses, heavily

overrepresented in the high-crime niche, were neither more nor less likely to experience firm closure than nonminority owners, controlling for firm, environmental, and owner traits. The firms of immigrant owners, in contrast, were more likely to remain in operation if they catered to a broad-market clientele. Although the serious impact of crime, as reported by owners, afflicts a small subset of urban businesses and is not a major determinant of small-firm viability in urban America, it actually appears to provide a net benefit -- improved survival prospects -- to the neighborhood firm subgroup reporting that it is most heavily shaped by its impact. The crime factor may be providing something of a protected market to those not fearing to operate in the types of business where its impact is greatest (Yoon, 1997). The nature of the market niches where crime’s impact is most often high is explored in further detail below.

\section{Market Segments in which Serious Crime Most Directly Impacts Young Firms}

Our final objective is to isolate more clearly the market sectors in which firm owners most often identify crime’s "strong negative impact” on their business operations. Table three breaks out young urban firms into two groups: 1) firms serving a neighborhood clientele; 2) firms serving a clientele that is broader in geographic scope city-wide, county-wide, regional, etc.Owner demographics differ noticeably in these two broad subsectors (table three). In the markets geographically defined as broader in scope, owners are overwhelmingly nonimmigrant as well as nonminority. Minorities own 25.1 percent of all young urban firms serving a neighborhood client base, but their ownership share in the broader market segment is just 11.3 percent. Immigrant owners mirror this 
pattern: their relative ownership share is over twice as high in the neighborhood-market sector than in the broader marketplace.

\section{Table three here}

The incidence of owners reporting crime's serious negative impact on their operations differs sharply across the neighborhood- and broad-market sectors. Crime thusly defined afflicts 5.6 percent of the neighborhood-oriented firms, which is over twice as high as the corresponding incidence typifying the broad-market small businesses (2.6 percent) (see table three).

Our next disaggregation includes neighborhood firms only, subdivided into 1) those selling to minority clients predominantly and 2) those selling largely to nonminorities. Thusly subdivided, an enormous demographic difference emerges: minority and immigrant owners are overwhelmingly concentrated in the neighborhood minority-clientele subsector (table four). Minority owners are four times more numerous in this sector (owning 57.6 percent of the businesses), relative to their presence in the nonminority neighborhood business sector (they own 15.1 percent of those firms). Immigrant owner concentrations are similarly skewed: they own 42.3 percent of the minority-sector firms but only 17.4 percent of those that cater to nonminority clients. The strong pattern is one of nonminority-owned firms serving nonminority clients while immigrant- and minority-owned firms serve the minority neighborhood market niche.

\section{Table four here}

Not surprisingly, serious crime’s major impact is noted disproportionately by owners of neighborhood firms serving minority clients: 9.6 percent of them report that crime seriously impacts the profitability of their businesses. Only 4.4 percent of firm 
owners catering to nonminority clients are similarly impacted (table four). While crime's negative impact is clearly greatest among the minority-oriented neighborhood firms, it is noteworthy that their firm characteristics are unlike those describing the subgroup of all firms experiencing major negative impacts of crime (table one). While these subgroups overlap, their mean firm traits are highly dissimilar. The subgroup made up entirely of firms facing major crime-related problems reports mean firm sales revenues, rate of discontinuance, and mean startup capitalization figures of $\$ 184,064$ (sales), 16.5 percent (closure), and $\$ 70,877$ (capital); corresponding figures for the minority-oriented neighborhood firms are \$76,276, 29.0 percent, and \$30,302. The minority-neighborhood firms as a subgroup are nearly 80 percent more likely to go out of business, while reporting less than half the mean sales revenues and startup capitalization, relative to the subgroup of all firms being seriously harmed by crime. The high-crime and minority neighborhood small business subgroups, in fact, differ dramatically in terms of firm and owner traits, with two exceptions - very large minority- and immigrant-owner overrepresentation typified both subgroups.

Data summarized in table four portray neighborhood-oriented firms serving minority clients as much more likely to go out of business than their counterparts selling to predominantly nonminority clienteles. Even when firm and owner traits are controlled for econometrically (table two), the minority-market-orientation characteristic predicts heightened likelihood of firms going out of business. A bank or a casualty-insurance company might examine these patterns and conclude, as Immergluck (1999) has suggested, that small firms doing business in urban minority communities are underperforming, in part, because their viability is harmed by the high incidence of 
crime. And patterns of owners identifying crime as a serious problem are over twice as numerous in the minority-neighborhood niche, relative to the nonminority neighborhood comparison group of small businesses (table four).

Evidence presented in this study indicates that serious crime, per se, is not the culprit responsible for the higher small-business closure rates typifying minority-oriented neighborhood businesses. This point is emphasized by re-estimating table two's logistic regression exercise solely for the neighborhood-firm subgroup and excluding the "crime" explanatory variables (see table five). In this regression exercise, the "minority market orientation" explanatory variable emerges with a coefficient value of -.907, which is highly significant statistically. If this variable is to be a useful proxy for high crime, and crime is assumed to be a net negative, then inclusion of crime explanatory variables would cause the minority-market-orientation variable coefficient to decline in size. In fact, the exact opposite occurs when measures of crime's impacts are introduced into the logistic regression analysis as explanatory variables (see table two): the negative minority-market-orientation variable coefficient becomes -1.390 . The clear implication is that the minority-neighborhood trait is not a useful proxy for those seeking to blame business closure patterns on crime patterns.

\section{Table five here}

\section{Concluding Remarks}

If this study is criticized for raising more questions than answers, we plead guilty. A summary of our conclusions follows, along with a list of issues that require further clarification to illuminate relationships between small-firm viability and urban crime. Michael Porter's observation that crime’s negative impact on inner-city business viability 
may be overstated is broadly supported by the evidence put forth in this study. Among the small-firm subgroups we have examined, most of the owners - whether serving regional or neighborhood markets, minority or nonminority clients - report that crime has no impact whatsoever upon the profitability of their business operations.

Among all young urban small businesses, 3.3 percent reported major negative impacts of crime (table one). The firm subgroup serving broadly-defined markets was less impacted, with only 2.6 percent of the owners identifying crime as having a significant negative impact on firm profits. The neighborhood market segment, where retail and consumer-service firms commonly deal face-to-face with their clientele, emerged as a relatively high-crime niche. Within this small-business subgroup, the minority-neighborhood-oriented niche reported a 9.6 percent major negative impact incidence for crime, while their counterparts serving predominantly nonminority clients reported a 4.4 percent rate. Yet, even in the highest crime niche identified by geographic scope or clientele demographics, most owners reported that crime has no impact upon business profitability (table four).

When owners do report that crime is having a major negative impact on the profitability of their business, can we infer that firm viability is likely to be undermined? The unambiguous answer is no. In the urban firm subset most hurt by crime, mean business traits included above-average annual revenues, high initial financial capitalization, and low rates of business discontinuance and closure, relative to firms not reporting serious crime issues.

On the narrow issue of urban crime and small-firm survival prospects, should we stop worrying and embrace crime? Is this an appropriate policy implication for banks and 
casualty insurance companies contemplating how best to target their loans and insurance policies? Table two's logistic regression analysis, after all, powerfully demonstrates the positive association of crime's impact with small-business survival prospects, holding firm, owner, and environmental traits constant.

We cannot embrace this conclusion. First, crime’s negative impact most likely depresses the rate of new firm formation in high-crime niches of the small-business community. Thus, the positive association of crime's severity with firm survival prospects most likely reflects the benefits existing firms derive when concerns over crime scare away most of their potential competitors. Our findings need to be extended by empirically examining crime's impact upon new-firm creation in urban America; only then can we begin to comprehend the overall impact of crime on the size and composition of the urban small-business community.

Furthermore, the firm owners operating in high-crime-impacted businesses may select into this sector based upon unobservable characteristics. They may be more knowledgeable than the broader population of potential and actual business owners regarding the nature and the likelihood of the types of crime that afflict these businesses. Alternatively, they may match owner traits and clientele characteristics in ways that lessen the costs of crime. Owners speaking Spanish and operating in markets where they serve Spanish-speaking co-ethnics, for example, may be able to deal with crime in less costly ways than owners lacking empathy with this particular clientele. How relevant are these unobservable traits? We have no idea, largely because they are unobservable. They come into play in the context of table 2's logistic regression exercise findings, however, in potentially powerful ways. 
Other factors constant, this exercise indicates that firms most seriously impacted by crime are more likely to remain in operation than firms reporting no impact. Are other factors really constant, or are unobservable characteristics varying systematically such that the seeming positive utility of serious crime is properly understood as correlated to unobserved owner traits that shape the ability of firms to achieve viability in a high-crime environment? A more complete specification of the logit regressions delineating firms closing down from those remaining active (table two) ideally would measure applicable owner traits that are presently unobserved. This is easier said than done.

\section{References}


Bates, Timothy, "Small Business Viability in the Urban Ghetto, Journal of Regional Science vol. 29 (4): 1989.

Bates, Timothy, “Entrepreneur Human Capital Inputs and Small Business Longevity,” The Review of Economics and Statistics vol. 72 (4): 1990.

Bates, Timothy, Race, Self-Employment and Upward Mobility (Baltimore: Johns Hopkins University Press, 1997).

The Boston Consulting Group, “The Business Case for Pursuing Retail Opportunities in the Inner City,” Initiative for a Competitive Inner City (ICIC) working paper, June 1998.

Craig, Ben, Jackson, William, and James Thomson, "Small Firm Credit Market Discrimination, SBA Guaranteed Lending, and Local Market Economic Performance," (Annals of the American Academy of Political and Social Social Science), Volume 613, September 2007.

Fairlie, Robert and Alicia Robb, "Why Are Black-Owned Businesses Less Successful than White-Owned Businesses: The Role of Families, Inheritances, and Business Human Capital” (Journal of Labor Economics, Volume 25, Number 2, April 2007).

Immergluck, Daniel, “Neighborhood, Race, and Capital,” Urban Affairs Review vol. 34 (2), pp. 397-411 (1999).

Jovanovic, Boyan, “Selection and Evolution of Industry,” Econometrica vol 50 (2): 1982.

Porter, Michael, “The Competitive Advantage of the Inner City,” Harvard Business Review vol. 73 (3), 1995. 
Porter, Michael, “New Strategies for Inner-City Economic Development,” Economic Development Quarterly vol. 11 (1), 1997.

Squires, Greggory, "Racial Profiling, Insurance Style: Insurance Redlining and the Uneven Development of Metropolitan Areas," Journal of Urban Affairs vol. 25 (4): 347-72.

Yoon, In-Jin, On My Own (Chicago: University of Chicago Press, 1997). 
Table 1: Firm and Owner Traits: Young Small Businesses Located in Metropolitan Areas

$\begin{array}{cll}\text { All Urban } & \text { Firms Reporting } & \text { Neighborhood } \\ \text { Small Businesses } & \begin{array}{l}\text { Strong Negative } \\ \text { Impact of Crime }\end{array} & \text { Firms Only } \\ & & \end{array}$

\section{A. Owner Characteristics}

1. Demographic Traits:

$\begin{array}{llll}\text { \% minority } & 14.6 \% & 36.1 \% & 25.1 \% \\ \text { \% immigrant } & 14.1 \% & 30.5 \% & 23.2 \%\end{array}$

2. Human-Capital Traits:

$\%$ high school or less

$29.1 \%$

$44.6 \%$

$36.3 \%$

$\%$ college graduate

$38.4 \%$

$21.0 \%$

$31.9 \%$

Hours worked in the firm

$$
\text { in } 1992 \text { (mean) }
$$

1,868

2,285

1,734

\section{B. Firm Characteristics}

Total sales revenues, 1992 (mean) \$117,681

$\%$ discontinued operations by late 1996

Startup capitalization (mean)

$\%$ with paid employees

\% started in 1990, 1991, or 1992

$\%$ serving neighborhood market

$\%$ serving minority clientele

$\%$ crime major negative impact

$\%$ crime minor negative impact
$23.2 \%$

$\$ 28,922$

$25.5 \%$

$47.8 \%$

$23.5 \%$

$13.9 \%$

$3.3 \%$

$13.9 \%$
$\$ 184,064$

$\$ 113,503$

$16.5 \%$

$\$ 70,877$

$38.6 \%$

$39.6 \%$

$39.4 \%$

$30.6 \%$

$100.0 \%$

$0 \%$
$29.0 \%$

$\$ 41,921$

$31.0 \%$

$55.4 \%$

$100.0 \%$

$23.1 \%$

$5.6 \%$

$16.5 \%$

Source: Characteristics of Business Owners database; base year 1992; year of owner survey, 1996; this version of the CBO database was released by census in 1998.

Table 2: Logistic Regression Analysis - Delineating Young Urban Firms Active in 1996 from those Discontinuing Operations and Closing Down between 1992 and 1996 
Neighborhood Market Broad Market Regression Coeffic. Regression Coeffic. coefficient std error coefficient std error

\begin{tabular}{|c|c|c|c|c|}
\hline Constant & $-3.688 *$ & 1.144 & $2.137 *$ & .710 \\
\hline \multicolumn{5}{|l|}{ Education: } \\
\hline College: $1-3$ years & $.793 *$ & .205 & $-.364 *$ & .108 \\
\hline College graduate & $.446^{*}$ & .231 & -.046 & .121 \\
\hline Graduate school & -.277 & .262 & $1.046^{*}$ & .182 \\
\hline $\begin{array}{l}\text { Prior work experience in a } \\
\text { similar firm }\end{array}$ & $.485 *$ & .164 & $.206^{*}$ & .089 \\
\hline $\begin{array}{l}\text { Prior work experience in a } \\
\text { family member's business }\end{array}$ & $-.882 *$ & .199 & $.510^{*}$ & .118 \\
\hline Owner age in years & $.249 *$ & .048 & $.132 *$ & .032 \\
\hline Owner age squared & $-.003^{*}$ & .001 & $-.001^{*}$ & .000 \\
\hline $\begin{array}{l}\text { Financial capital at } \\
\text { startup }(\$ 000)\end{array}$ & .000 & .001 & $.002 *$ & .001 \\
\hline Firm started de novo & -.323 & .210 & -.016 & .133 \\
\hline Year entered, 1990, or later & -.158 & .168 & $-.554 *$ & .090 \\
\hline Owner labor input in hours & -.012 & .008 & -.003 & .004 \\
\hline Minority-owned firm & .493 & .290 & -.000 & .169 \\
\hline Immigrant-owned firm & .100 & .288 & $.804^{*}$ & .186 \\
\hline Female-owned firm & $-1.286^{*}$ & .165 & .019 & .094 \\
\hline Employer firm & $.722 *$ & .112 & $.707^{*}$ & .134 \\
\hline Minority market orientation & $-1.391^{*}$ & .250 & -.085 & .157 \\
\hline Crime: a major problem & $1.390 *$ & .529 & .372 & .327 \\
\hline Crime: a minor problem & $1.757 *$ & .385 & .228 & .141 \\
\hline $\begin{array}{l}\mathrm{N} \\
-2 \text { Log L } \\
\text { Chi square }\end{array}$ & $\begin{array}{c}1,274 \\
1,054.1 \\
265.4\end{array}$ & & $\begin{array}{l}3,402 \\
3,329.7 \\
362.2\end{array}$ & \\
\hline
\end{tabular}

* Statistically significant, .05 significance level.

Table 3: Traits of Urban Firms and Owners in Geographically-Defined Market Segments 


\begin{tabular}{ll}
$\begin{array}{l}\text { Neighborhood } \\
\text { Market }\end{array}$ & $\begin{array}{l}\text { Broad } \\
\text { Market }\end{array}$ \\
\hline
\end{tabular}

Owner demographics

$\begin{array}{lll}\% \text { minority } & 25.1 \% & 11.3 \% \\ \% \text { immigrant } & 23.2 \% & 11.4 \%\end{array}$

$\underline{\text { Firm characteristics }}$

Total sales revenues, 1992 (mean) \$113,503

$\$ 119,300$

$\%$ closing down by 1996

$22.1 \%$

$23.5 \%$

\% serving minority

markets

$23.1 \%$

$10.7 \%$

Crime's impact:

none

$77.9 \%$

$84.6 \%$

minor

$16.5 \%$

$12.8 \%$

major

$5.6 \%$

$2.6 \%$

Source: CBO database

Table 4: Traits of Firms and Owners and the Impact of Crime (Firms serving neighborhood markets only) 
Minority

$\underline{\text { Clientele }}$

Owner demographics

$\%$ minority

$\%$ immigrant

$\underline{\text { Firm characteristics }}$

Total sales revenues, 1992 (mean)

$\%$ closing down by 1996

Crime's impact:

none

minor

major

Source: CBO database
$57.6 \%$

$42.3 \%$

$15.1 \%$

$17.4 \%$

Nonminority

$\underline{\text { Clientele }}$

$$
\$ 76,276
$$

$29.0 \%$

$60.1 \%$

$30.3 \%$

$9.6 \%$
$21.2 \%$

$\$ 124,199$

$83.0 \%$

$12.6 \%$

$4.4 \%$

Table 5: Logistic Regression Analysis - Among Neighborhood-Oriented Firms Operating in 1992, Delineating Small Businesses Still Active at the End of 1996 from Closures 


\section{Regression Coefficient \\ $\underline{\text { Explantory variables }}$ \\ coefficient std error}

\begin{tabular}{|c|c|c|}
\hline Constant & $-4.373^{*}$ & .566 \\
\hline \multicolumn{3}{|l|}{ Education: } \\
\hline College: $1-3$ years & $.946 *$ & .195 \\
\hline College graduate & $.796 *$ & .215 \\
\hline Graduate school & -.230 & .250 \\
\hline Prior work experience in a similar firm & $.509 *$ & .157 \\
\hline $\begin{array}{l}\text { Prior work experience in a family } \\
\text { member’s business }\end{array}$ & $-.832 *$ & .189 \\
\hline Owner age in years & $.280 *$ & .047 \\
\hline Owner age squared & $-.003^{*}$ & .001 \\
\hline Financial capital at startup (\$000) & .000 & .001 \\
\hline Firm started de novo & $-.494 *$ & .195 \\
\hline Year entered, 1990, 1991 or 1992 & -.202 & .158 \\
\hline Owner labor input in hours $(00)$ & -.011 & .007 \\
\hline Minority-owned firm & .323 & .256 \\
\hline Immigrant-owned firm & .136 & .263 \\
\hline Female-owned firm & $-1.341^{*}$ & .155 \\
\hline Employer firm & $1.099 *$ & .223 \\
\hline Minority market orientation & $-.907 *$ & .212 \\
\hline
\end{tabular}

$\mathrm{N}$

1383

$-2 \log \mathrm{L}$

1171.0

Chi-square

265.2

* Statistically significant, .05 significance level. 


\section{Data Appendix: the CBO Data}

A. Variable Definitions, logistic regressions:

Regression analysis dependent variable: Active (or survive) --Firm stayed in business over the period 1992-1996, irrespective of presence or absence of ownership changes, then active $=1$; otherwise, active $=0$.

Female-owned firm: Firm owner is female, then female-owned firm=1; otherwise, female-owned firm $=0$.

Minority-owned firm: Firm owner is Hispanic, Black, Asian, or Native American. In multi-owner firms, the minority-owned share is $51 \%$ or higher, then minority-owned firm=1; otherwise, minority-owned firm $=0$.

Immigrant-owned firm -- Firm owner is an immigrant (not born in the US), then immigrant-owned firm=1; otherwise, immigrant-owned firm=0.

Owner age in years - self explanatory.

Owner Age squared - self explanatory.

High school (excluded variable) -- Education level of owner, has high school degree only or less, then high school=1; otherwise, high school=0.

College, 1-3 years -- Education level of owner, has some college, then college 1-3 years $=1$; otherwise, college $1-3$ years $=0$.

College graduate -- Education level of owner, has a college (bachelor's) degree, then college graduate $=1$; otherwise, college graduate $=0$.

Graduate school -- Education level of owner, has some post-graduate education (masters, Ph.D., etc.), then graduate school=1; otherwise, graduate school=0.

Prior work experience in a similar business -- Previously worked in a business similar to the one now owned, then this variable $=1$; otherwise, $=0$.

Prior work experience in a family member's business -- Has worked in the past for a parent or relative who owned a business, then this variable $=1$; otherwise $=0$.

Financial capital at startup - Amount of financial capital invested to start the firm.

Minority market orientation - Firm serve primarily minority clientele (more than 50\%)

Crime: a major problem: Crime had a significant negative impact on firm profits. 
Crime: a minor problem: Crime had a somewhat negative impact on firm profits. 